\title{
MEDICO ETHNOBOTANICAL STUDY OF ANTIMICROBIAL EFFECTS AND OTHER HEALTH BENEFITS ON NINE DEVINE PLANTS OF NAVAPATRIKA
}

\author{
Kar Rishav \\ Department of Microbiology \\ Ramakrishna Mission Vivekananda centenary \\ College, Rahara, Kolkata, West Bengal, India
}

\begin{abstract}
India is always being a rich country by its spirituality and cultural aspects, but the thing; that is yet to explore fully is the scientific temperament behind the spirituality. The transformation of wild plants into bountiful, reliable crops profoundly altered the trajectory of modern humans. In India there are many blessed plants are prehistorically used through the linage of anthropological and ethnobotanical significance. Navapatriaka pants are one of that blessed plants which are mainly associated with the eastern part of India, specifically in the land of Bengal provinces. Food, Medicine \& Shelter these are the primary necessitates of each nation, these nine plants are fulfilling all such dictum of colloquial livelihood of Bengal peoples. Through the Ayurveda to the modern pharmacological qualification and both quantification of these plants are already tested, but in this review we tried to spot out the antimicrobial efficiency of these holy plants for their future application of immunoglobulin associated study.
\end{abstract}

Key words: Antimicrobial efficiency, cultural inheritance, indigenous groove, socio-ecology.

\section{INTRODUCTION}

The Indian subcontinent is the landscape of living traditions, protracted from the time of human civilization. A number of indigenous and endemic plants are domesticated for food, spice and medicines as per the palaeo-anthropological record of India (Piperno, 2011). The colonization of the human environment by plants, and the consequent evolution of domesticated forms are increasingly being viewed as a co-evolutionary plant-human process that occurred over a long time period, which evidence for the co-evolutionary relationship between plants and humans reaching ever deeper into the hominin past (Allaby et al., 2015). From the view of metagenomics, the co-evolutionary

\author{
Pal Sujoy \\ Department of Microbiology \\ Ramakrishna Mission Vivekananda centenary \\ College, Rahara, Kolkata, West Bengal, India
}

gene pool may be a customized with the help of microbial interaction with the plant secondary metabolites (Rajasekaran et al., 2009).

Plants have been an indispensable part of Indian life and traditions; hence all aspects of folk literature of this country have enormous references about trees, shrubs, climbers and their flowers and fruits which do not sojourned the linage of common past (Amirthalingam, 2015). The tradition of Ayurveda solicits to lop off the specific demographic medicine knowledge into folk medicine and practices, which are proliferating and specified for sectarian culture in various parts of India. Folk songs are particularly rich in references to flowers and fruits. The songs sung on various occasions from birth to death, at the times of joy and sorrow, in festivals, ceremonies and rites. Folk proverbs having references to plants are indicative of the deep insight, common sense and practical wisdom of the common folk (Chaudhuri \& Pal, 1997). Not only in traditional songs, but in traditional tales, mythological stories and events in the epics, as also innumerable religions practices of worship in the house hold, in temples, festivals, one all replete with references to plants.

Divinity is a traditional practice by mean specific plants or a grove is not only majestically treated but also protected. There is a conceptual difference between 'blessed', 'sacred' and 'holy' plants; the difference does not only pertain to the semantic meaning of words but also on the worship of trees (Amirthalingam, 2015). These practices can be traced from the prehistoric to modem times in an unbroken line. A large number of plants are considered as temple trees and used as sacred and symbol of certain Hindu Gods Starting from Rig Veda up to the classical times there are many Sanskrit works which gave valuable information regarding the plants. This is also marked that, the Vedas contain information about various plants which are not well traced today; the saga of those 
vegetations are completely lost due to the some obvious or non protective cause.

Navapatrika means nine plants in Sanskrit, this is the abacus of common nine plants of Bengal; they are Aegle marmelos, Punica granatum, Oryza sativa, Curcuma longa, Sesbania sesban, Colocasia esculenta, Musa paradisiaca, Alocasia macrorrhiza and Saraca asoka. The ritualistic use of Navapatrika in Bengal Providences is mainly observed during the time of early autumnal annual festival Durga Puja. This ritual is done as a method to invoke the Goddess using the nine plants as the living medium. Many have even opined that the Navapatrika is a form of Durga herself, which symbolises all the aspects of nature in a complex vegetative state. It could just have been a local or a primitive practice of worshipping the Mother Earth for a rich annual harvest and with the popularity of the Durga Puja, this ritual was assimilated in the festivities. In fact, the worshipping of Navapatrika in its original form is still prevalent in some parts of Eastern India (Bhattacharya, 1977).

A large number of plant products exhibit antimicrobial property and this supports the contention that traditional medicine remains a valuable resource in the potential discovery of natural product pharmaceuticals (Cowan, 1999). Due to emergence of drug resistant strains of various infectious microbes, ethnobotany may provide new effective pharmaceutical alternatives to existing drugs (Ghorbani et al., 2006). We can say that in recent days researchers of different fields turn their research into the ways which are already documented in our cultural manuscripts (Bhattacharya, 1977). In other hand due to indiscriminate use of antibiotics many microorganisms become antibiotic resistant. We slowly are fetching a situation where almost every pathogenic microorganism becomes Anti Microbial drug Resistance (AMR) that ultimately results in failure of currently available drugs even third generation antibiotics will also get non effective. Recently CDC (Centre for Disease Control) estimates that in US nearly 2 million people get infected by AMR and around 2300 people die due to this. Not only that, day by day occurrence of various critical diseases becomes more and more prominent such as AIDS, cancer etc (CDC 2019). Synthetic drugs available for the treatment either have very high cost or have side effects on health which are also hazardous. This turns the interest of research into natural antibiotics derived from plants. Those natural medicines are mainly phytochemical products having almost no side effects on health. Most importantly these drugs will be cheaper than synthetic drugs and will be affordable by all sorts of people in the society.

\section{ANTIMICROBIAL AND OTHER MEDICINAL PROPERTIES OF THESE NINE PLANTS}

These nine plants of Nabapatrika have enormous antimicrobial activities and tremendous health benefits. Some of them are already documented and some are yet to explore fully. These qualities are noted here-

\section{Aegle marmelos}

Antimicrobial activity: It has antimicrobial properties against various potential pathogens like Pseudomonas aeruginosa, Roultella plantikola, Penicillium chrysogenum, Candida albicans. Methanolic extraction and extraction in petroleum ether, chloroform of the fruit and leaf of the plant shows zone of inhibition against those pathogenic bacteria and fungus (Meena et al. 2016). The zone of inhibition is comparable to that of the standard antibiotic Amoxicillin. It has the ability to inhibit the diarrhea causing pathogens like $S$. dysenteriae, S. flexneri, S. sonnei. Plasmodium falciperum the causative agent of malaria is also gets affected by root extraction of the plant following a method of Trager and Jensen. Wood apple is also a potential virucidal agent that has antiviral activity against Ranikhet disease virus. Hydro alcoholic extract of the fruits have already been reported to show interferon like activity against the same virus (Gupta et a.,l 2015).

Other medicinal values: Potential phyto compounds present in this plant has many therapeutic applications against many radial mediated ailments. Methanolic crude extract of $A$. marmelos has best anti oxidant and ROS scavenging activity on macrophage cells. Apart from that it is also used in treatment of heart diseases and in case of constipation (Bhar et al.2019).

\section{Punica granatum}

Antimicrobial activity: It is mainly used in treatment of oral infections. Common micro flora marked as potential oral infective agents are mainly Streptococcus sp., $\quad$ Staphylococcus sp., Lactobacillus sp. and Candida sp. It has already been reported by researchers that seed extraction of pomegranate shows bactericidal and bacteriostatic activity due to the presence of ellagitannins and punicalagin. Haemozoin or TNF decreases due to increase in the level of MMP 9 mRNA in presence of pomegranate extract thus preventing malaria. Not only that, pomegranate juice has the ability to block the CD4 and CXCR5/CCR5 viral binding site thereby acting as anti viral agent against HIV (Hemani \& Gheena, 2018). 
Other medicinal values: Apart from anti viral and anti microbial activities this plant has many other health benefits also. It is used as ointments to heal sepsis and in treatment of insomnia, memory loss, internal bleeding, and intestinal disorders (Bhattacharya 1977) and in case of heavy menstrual bleeding (HMB) (Bryant-Smith et al., 2018; Goshtasebi, 2015).

\section{Saraca asoka}

Antimicrobial activity: Ashoka is one of the most important medicinal plants, it has enormous antimicrobial activity. Ethanolic and petroleum ether extract of the plant shows inhibitory activity against Bacillus Subtilis and Pseudomonas aeruginosa (Shilpakala Sainath, 2009). It has already been reported that aqueous extraction of the stem of the plant shows antibacterial activity against Bacillus cereus, Klebsiella pneumoneae, Proteus mirabilis, and Staphylococcus areus (Singh et al., 2015).

Other medicinal values: This plant has enormous medicinal values. It is very much used in treatment of heart diseases, gastrointestinal diseases, pregnancy related disorders (Bhattacharya, 1977), and in arthritis and it is also a potential blood clotting agent (Chakraborty et al., 2014).

\section{Curcuma longa}

Antimicrobial activity: It is an already documented natural antibiotic. Ethanolic extraction of leaves of C.long shows antibacterial activity against bacillus subtilis, Klebsiella pneumoneae, Staphylococcus aureus, and Pseudomonas aeruginosa (Singh et al., 2015)

Other medicinal value: Turmeric is a very common material in our kitchen apart from that it has tremendous beneficial effects on our health in both externally and internally. It is used in treatment of allergy, liver problem, stammering, asthma and in many other skin related problems (Bhattacharya, 1977), Joint Arthritis (James et al., 2016) and Parkinson's disease (Wang et al., 2017).

\section{Musa paradisiaca}

Antimicrobial activity: It has an outstanding antibacterial activity against Gram positive bacteria than Gram negative bacteria (Karadil et al., 2011). The fruit peel extract $(10 \mu \mathrm{g} / \mathrm{ml})$ shows zone of inhibition around $12.2 \pm 0.1 \mathrm{~mm}$ against Bascillus subtilis and around $8 \mathrm{~mm}$ zone of inhibition against Escherichia coli (Asoso et al., 2016) It shows antifungal properties too, zone of inhibition around $13 \pm 0.4 \mathrm{~mm}$ is shown against fungal strain Candida albicans (Rajesh , 2017; Mallick et al., 2007)
Other medicinal values: Banana is a very common and available food item that we frequently use in our daily diet routine. But this plant has several beneficial effects on our health, from ancient times it is used in treatment coughing, intestinal disorders, mental depression (Bhattacharya, 1977), diabetes (Shruthi, 2019), in many skin problems, and tumour (Harsha Raj et al., 2017).

\section{Colocasia esculenta}

Antimicrobial activity: This plant of Navapatrika is one of the most well known medicnal plant having antimicrobial activities. It has strong inhibitory effect against Streptococcus mutans and Klebsiella pneumoniae. Both of the bacteria are highly pathogenic to humans. Ethanol extract of the plant show zone of inhibition against various gram positive and gram negative bacteria such as E.coli, Proteus mirabilis, Enterococcus sp, Salmonella sp, Pseudomonas aeruginosa and Staphylococcus areus (Singhl et al., 2011; Chakraborty et al., 2015)

Other medicinal values: It is potentially used to maintain healthy vision, skin, mucous membrane, lungs etc. It also has anti depressant and sedative activity used in treatment of hypoglycaemia (Harshal et al., 2018).

\section{Alocasia macrorrhiza}

Antimicrobial activity: An anti-fungal protein alocasin is isolated from it of $11 \mathrm{kda}$ molecular weight (determined by SDS-PAGE). It showed antifungal activity against Aspergilluniger, Candida albicans and Saccharomyces cerevisiae. The ethanolic extract of alocasia shows profound inhibitory property Staphylococcus aureus and Klebsiella pneumonia (Banik et al., 2014)

Other medicinal values: This plant has antioxidant and DPPH scavenging activity along with thrombolytic and cytotoxic effects also (Singh et al., 2017).

\section{Sesbania sesban}

Antimicrobial activity: It is a well known medicinal plant having enormous antimicrobial activities. Ethanolic, methanolic and aqueous extraction of leaves shown inhibitory activity against gram negative pathogenic bacteria like $E$. coli, Pseudomonas aeruginosa, Klebsiella pneumoneae (Nirosha et al., 2019)

Other medicinal values: Due to the presence of various medicinal qualities this plant has wide range of uses. It has potential anti-inflammatory 


\section{International Journal of Engineering Applied Sciences and Technology, 2020 Vol. 5, Issue 3, ISSN No. 2455-2143, Pages 377-382 \\ Published Online July 2020 in IJEAST (http://www.ijeast.com)}

activity (Bhattacharya, 1977), anti-oxidant activity; anti-diabetic activity apart from that it is also used in control of fertility and spermicidal activity. (Goswami et al., 2016)

\section{Oryza sativa}

Antimicrobial activity: The antifungal activity of OsTDX protein against mold and yeast is well documented. The antifungal activity of this protein was stronger in yeast than in mold fungi owing to the differences in their cell wall components (Park et al., 2019). OsTDX protein exerted killing action against fungal pathogens via destabilizing and disrupting effects on fungal membranes.

Other medicinal values: Indians specially in Bengali community rice can be defined as the chief item of their meal. Appart from that rice has many beneficial activities on health also. It has redox homeostasis (Bhattacharya, 1977) and antioxidant property as well (Palungwachira, 2019; Rungratanawanich, 2018)

\section{CONCLUSION}

Advancement of modern day research based on various modern technologies is nothing but the advancement of civilization, beside that this phytochemical research is also a rising sphere in the research field. In spite of much advancement we cannot solve the whole mystery of our mother nature. Nature is a very rich source of many things which are yet to explore fully. Numerous plants in earth have tremendous high medicinal qualities. Plant products will be more available and have almost no side effects unlike the present markedly available drugs. Some of them are already documented in our cultural manuscripts. Recent day scientist's works on few of those plants to see their anti-microbial activities and other medicinal qualities but majority of the details of their uses are yet not published documented scientifically. Indians have already much knowledge about these phyto-chemical compounds of many medicinal plants and their proper scientific uses. Hence India will have to take the lead in this rising area of research. But the responsibility does not comes to an end until these the products will become available in the market for uses. In recent days many works are already going on regarding these phyto-chemical studies but these nine plants which are mentioned here are not markedly available as potential drugs. Curcuma longa and Aegles marmelos though have some markedly available products but remaining seven plants are not as popular as potential therapeutics till now. There are many other medicinal plants whose qualities are yet to apply in our daily life as drugs and these nine plants mentioned here represents of them all.

\section{ACKNOWLEDGEMENT}

Authors are thankful to the HOD, Department of Microbiology of RKMVC College for giving some ardent help and suggestions during the preparation of this review manuscript.

\section{REFERENCES}

1 Allaby RG, Kistler L, Gutaker RM, Ware R, Kitchen JL, Smith O and Clarke AC. (2015). Archaeogenomic insights into the adaptation of plants to the human environment: pushing plantehominin co-evolution back to the Pliocene, Journal of Human Evolution, 79,(pp.150-157).

2 Amirthalingam M. (2015). Sacred Plants of West Bengal in Ecological Traditions of India, volume - xii, published by- C.P.R. Environmental education centre; A centre of excellence of the ministry of environment, Forests and climate change, government of India. ENVIS centre Www.cpreecenvis.nic.in.

3 Asoso OS, Akharaiyi FC and Animba LS. (2016). Antibacterial Activities of Plantain (Musa paradisiaca) Peel and Fruit. Scholars Research Library Der Pharmacia Lettre, 8(5), (pp.5-11).

4 Banik S, Ibrahim Md., Amin Md. N, Moghal Md. MR, Majumder MS, Alam MK, Anonna SN and Rashed MSF. (2014). Determination of biological properties of Alocasia Macrorrhizos: A Medicinal Plant World Journal of Pharmaceutical Research Volume 3(9), (pp-193-210).

5 Bhar K, Mondal S and Suresh P. (2019). An Eye-Catching Review of Aegle marmelos L., Pharmacognosy Journal, 11 (2), (pp.207-224).

6 Bhattacharya S. (1977). Chiranjib Bonousodhi, vo.2:1-5, Ananda Publishers Pvt. Calcutta. ISBN 978-81-7066-607-3.

7 Bryant-Smith AC, Lethaby A, Farquhar C and Hickey M.(2018). Antifibrinolytics for heavy menstrual bleeding. Cochrane Database of Systematic Reviews, Issue 4. Art. No.: CD000249.

8 CDC. (2019). Antibiotic Resistance Threats in the United States, 2019. Atlanta, GA: U.S. Department of Health and Human.

9 Chakraborty P, Deb P, Chakraborty S, Chatterjee B and Abraham J. (2015). 


\section{International Journal of Engineering Applied Sciences and Technology, 2020 \\ Vol. 5, Issue 3, ISSN No. 2455-2143, Pages 377-382 \\ Published Online July 2020 in IJEAST (http://www.ijeast.com)}

Cytotoxicity and antimicrobial activity of Colocasia esculenta. Journal of Chemical and Pharmaceutical Research 7(12), (pp.627-635).

10 Chakraborty R, Sen S, Deka MK, Rekha B and Sachan S. (2014). Anti-Microbial Evaluation of Saraca indica Leaves Extracts by Disk Diffusion Method. Journal of Pharmaceutical, Chemical and Biological Sciences February, 1(1), (pp.01-05).

11 Chaudhuri RHN and Pal DC. (1997). Plants in Folk religion and mythology (pp-17-24), In Jain SK, Contribution on Indian Ethnobotany, $3^{\text {rd }}$ Ed. Scientific Publishers, Jodhpur.

12 Cowan MM.(1999). Plant Products as Antimicrobial Agents, Clin Microbiol Rev. 12(4), (pp.564-582).

13 Ghorbani A, Naghibi F and Mosaddegh M. (2006). Ethnobotany, Ethnopharmacology and Drug Discovery, Iranian Journal of Pharmaceutical Sciences Spring, 2, (pp.109118).

14 Goshtasebi A, Mazari Z, Gandevani SB and Naseri M. (2015). Anti-hemorrhagic activity of Punica granatum $L$. flower (Persian Golnar) against heavy menstrual bleeding of endometrial origin: a double-blind, randomized controlled trial. MJIRI, 29, (pp.199).

15 Goswami S, Mishra KN, Pal Singh R, Singh P. (2016). Sesbania sesban, A Plant with Diverse Therapeutic Benefits: An Overview Ravindra et al. SGVU Journal of Pharmaceutical Research \& Education, 1(1), (pp-111-121).

16 Gupta A, Jagtap R and Chaphalkar S. (2015). Flow cytometric evaluation of anti-viral activity of Aegle marmelos against Newcastle disease virus, International Journal of Research in Pharmacy and Life Sciences 3(2), (pp-283-287).

17 Harsha Raj M, Ghosh D, Banerjee R and Salimath BP. (2017). Suppression of VEGFinduced angiogenesis and tumor growth by Eugenia jambolana, Musa paradisiaca, and Coccinia indica extracts. Pharmaceutical biology 55(1), (pp-1489-1499).

18 Harshal AP, Choudhary PD and Kamat SR. (2018). An Overview of Traditionally Used Herb, Colocasia esculenta, as a
Phytomedicine. Med Aromat Plants (Los Angeles), 7, (pp-4).

19 Hemani K and Gheena S. (2018). Evaluation of Antimicrobial Property of Extract of Punica Granatum (L.) on Oral Pathogens. International Journal of Pharma and Bio Sciences, 8(3), (pp-35-40).

20 James W Daily, Yang M and Park S. (2016). Efficacy of Turmeric Extracts and Curcumin for Alleviating the Symptoms of Joint Arthritis: A Systematic Review and MetaAnalysis of Randomized Clinical Trials, Journal of Medicinal Food J Med Food, 19(8), (pp-717-729).

21 Karadil RV, Shah A, Parekh P and Azmi P. (2011). Antimicrobial Activities of Musa paradisiaca and Cocos nucifera. International Journal of Research in Pharmaceutical and Biomedical Sciences, 2, (pp.1).

22 Mallick C, Chatterjee K, GuhaBiswas M and Ghosh D. (2007). Antihyperglycemic effects of separate and composite extract of root of Musa paradisiaca and leaf of Coccinia indica in streptozotocin-induced diabetic male albino rat, Afr. J. Trad. Cam. 4(3), (pp.362 - 371).

23 Meena RK, Pareek A and Meena RR. (2016). Antimicrobial activity of Aegle marmelos (Rutaceae) plant extracts, International Journal of Medi Pharm Research, 2(1), (pp.01-05).

24 Nirosha M, Pavani K, Priya AK, Haseena U and Jyothsna S. (2019). Antimicrobial Activity of Organic Leaf Extract of Sesbania Sesban Against Gram Negative Pathogenic Bacteria. International Journal of Life science and Pharma Research, 9(2), (pp.31-38).

25 Palungwachira P, Tancharoen S, Phruksaniyom C Klungsaeng S, Srichan R, Kikuchi K and Nararatwanchai T. (2019). Antioxidant and Anti-Inflammatory Properties of Anthocyanins Extracted from Oryza sativa L. in Primary Dermal Fibroblasts Oxidative Medicine and Cellular Longevity Volume 2019, Article ID 2089817, 18 pages.

26 Park SC, Kim IR, Hwang J, Kim JY, Jung YJ, Choi W, Lee Y, Jang MK and Lee JR. (2019). Functional Mechanisms Underlying the Antimicrobial Activity of the Oryza sativa Trx-like Protein . International Journal o f Molecular Sciences, 20(6), (pp.1413). 
27 Piperno DR. (2011). The Origins of Plant Cultivation and Domestication in the New World Tropics, Current Anthropology, 52, (pp.4).

28 Rajasekaran R, Gomathi A and Narayana A. (2009). Medico Historical Study of a Siddha Drug 'Vilvam' (Aegle marmelos. Linn), Journal lnd. Med. Heritage, 39, (pp.171-190).

29 Rajesh N. (2017). Medicinal benefits of Musa paradisiaca (Banana), International Journal of Biology Research, 2(2), (pp.51-54).

30 Rungratanawanich W, Maurizio M and Daniela U. (2018). Redox Homeostasis and Natural Dietary Compounds: Focusing on Antioxidants of Rice (Oryza sativa L.). Nutrients, 10, (pp-1605).

31 Shilpakala Sainath R, Prathiba J and Malathi R. (2009). Antimicrobial properties of the stem bark of Saraca indica (Caesalpiniaceae). European Review for Medical and Pharmacological Sciences, 13, (pp.371-374).

32 Shruthi D. (2019). Medicinal uses of banana (Musa paradisiaca). Drug Invention Today, 12, (pp.1).

33 Singh N, Gupta S and Rathore V. (2017). Comparative Antimicrobial Study of Ethanolic Extract of Leaf and Rhizome of Curcuma longa Linn. Pharmacogn Jornal, 9(2), (pp-208-212).

34 Singh S, Anantha Krishna TH, Subban K, Gini CK, Valayil JM and Jayabaskaran C. (2015). Phytomedicinal importance of Saraca asoca (Ashoka): an exciting past, an emerging present and a promising future, Current Science, 109(10), (pp.1790).

35 Singh SK, Patel JR, Dangi A, Bachl D and Katariya RK. (2017). A Review Paper On Alocasia macrorrhiza Tradional Indian Medicinal Plant. European Journal of Pharmaceutical And Medical Research, 4(2), (pp-366-375).

36 Singhl B, Kumar NK and Dwivedi SC. (2011). Antibacterial and Antifungal Activity of Colocasia esculenta Aqueous Extract: An Edible Plant. Journal of Pharmacy Research, 4(5), (pp-1459-1460).

37 Wang XS, Zhang1ZR, Zhang1MM, Sun MX, Wang WW and Xie CL. (2017). Neuroprotective properties of Curcumin in toxin-base animal models of Parkinson's disease: a systematic experiment literatures review. BMC Complementary and Alternative Medicine, 17, (pp-412). 